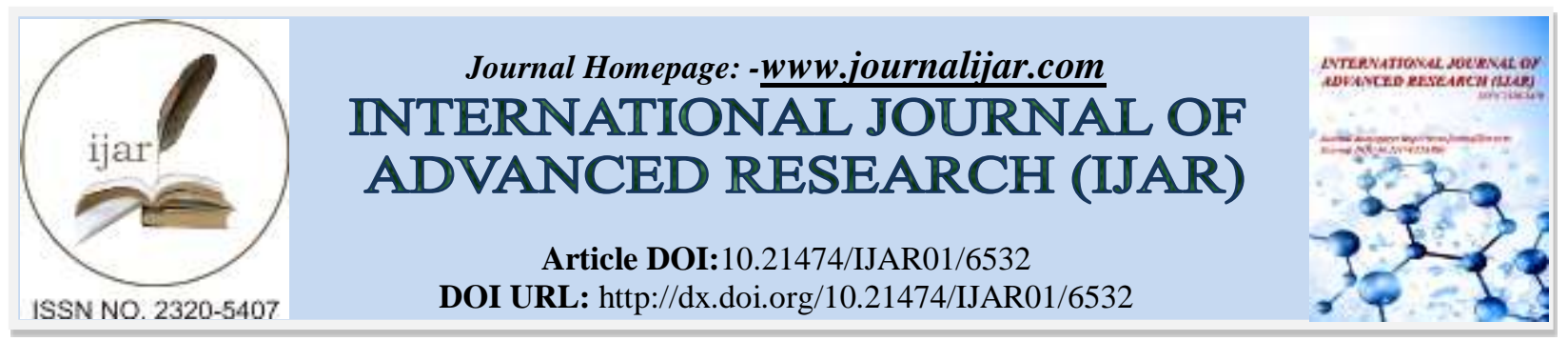

RESEARCH ARTICLE

\title{
ANALYSIS OF GENETIC VARIATION IN DIFFERENT BANANA VARIETY (MUSA) SPECIES BY RANDOM AMPLIFIED POLYMORPHIC DNA.
}

\author{
P. Karunambika ${ }^{1}$, Dr. K. P. Renuka Devi ${ }^{2}$ and Dr. S. F. Maleeka Begum ${ }^{3}$. \\ 1. III.B.Sc Biotechnology, Department of Biotechnology, Sri Krishna Arts and Science College, Coimbatore. \\ 2. Assistant Professor, Department of Biotechnology, Sri Krishna Arts and Science College, Coimbatore. \\ 3. Head, Department of Biotechnology, Sri Krishna Arts and Science College, Coimbatore.
}

\section{Manuscript Info}

Manuscript History

Received: 14 December 2017

Final Accepted: 16 January 2018

Published: February 2018

Keywords:-

RAPD, Amplification, Genetic variation.

Gel electrophoresis.

\begin{abstract}
Banana plant is one of the most important food crops in the world. It also has rich source of carbohydrates, vitamin-B and also provides good source of essential ions and nutrients. The multipurpose use of this plant has attracted the global attention which promotes many researchers to conduct preliminary studies on genetic diversity of this plant. The current study was focused to study the DNA finger print and asses the genetic diversity among the varieties of banana. A total of five banana cultivars were collected in and around Coimbatore. The DNA was isolated from the samples and confirmed by random agarose gel electrophoresis with respective markers. The dendrogram was constructed using a 1D advanced software, D Gel DAS (Digital Gel Documentation Analysis Software).The coefficient ranged for Rasthali and Pooven is 0.749.Red banana and Nendran false between 0.857. The highest coefficient is showed by Grand nine variety of 0.873 .
\end{abstract}

Copy Right, IJAR, 2018. All rights reserved.

\section{Introduction:-}

Banana (musa acuminate colla) is the best known tropical fruit. It is one of the economical important fruit crops grown in Bangladesh in both homestead and commercial farms Uganda National Council for Science and Technology (UNCST). Banana and plantain constitute the fourth most important staple food commodity of the world, after rice, wheat and maize (Padam et .al 2012). Ripe banana mixed with rice and milk is the traditional dish for Bangladesh. The improvement of musa spp, by traditional breeding programs is difficult and time consuming process because of high sterility, polyploidy and long generation times to get an ultimate edible variety Brarl. et al., (2009).

\section{Materials and Methods:- \\ Plant material collection:-}

The mother plant were collected from SPIC Agro farm, Coimbatore, India and maintained in the green house and the fresh leaves from the plant were used for the study.

\section{Isolation of genomic DNA:-}

One gram of fresh leaf sample was ground in liquid nitrogen and suspended in $20 \mathrm{ml}$ of $2 \mathrm{X}$ CTAB extraction buffer [3\% CTAB, $100 \mathrm{mM}$ Tris (pH 8.0), $20 \mathrm{mM}$ EDTA (pH 8.0), $1.4 \mathrm{M} \mathrm{NaCl}, 3 \%$ PVP and 0.1\% -Mercaptaethanol], the 
suspension was incubated at $60^{\circ} \mathrm{C}$ for 45 minutes, then brought down to room temperature. An equal volume of chloroform: isoamylalcohol (24:1) was added, centrifuged at 10,000 rpm (revolution per minute) for 15 minutes at $4^{\circ} \mathrm{C}$, supernatant was collected into fresh tube and previous step was repeated twice. Finally, supernatant was transferred to fresh tube. $0.2 \mu \mathrm{l}$ of $\mathrm{NaCl}$ was added and mixed gently, and then one volume of ice-cold isopropanol was added, mixed gently and incubated overnight at $4^{\circ} \mathrm{C}$.Next day, contents were centrifuged at $10,000 \mathrm{rpm}$ for 20 minutes at $4^{\circ} \mathrm{C}$. Supernatant was discarded, the DNA pellet was washed twice with $70 \%$ ethanol, air dried for 30 minutes and dissolved in $500 \mu \mathrm{l}$ of TE buffer $(10 \mathrm{mM}$ Tris $\mathrm{HCl}, \mathrm{pH} 8.0$ and $1 \mathrm{mM}$ EDTA, pH 8.0). Further, it was treated with $3 \mu \mathrm{l}$ RNase $(10 \mathrm{mg} / \mathrm{l})$ at $37^{\circ} \mathrm{C}$ for 1 hour. Then it was extracted with equal volume phenol: chloroform: isoamylalcohol $(25: 24: 1)$ at $10,000 \mathrm{rpm}$ for 10 minutes at room temperature. The DNA was precipitated with $95 \%$ chilled ethanol in the presence of $0.3 \mathrm{M}$ sodium acetate $\left(\mathrm{pH} \mathrm{5.2)}\right.$ at $-20^{\circ} \mathrm{C}$ for 2 hours and pelleted at $10,000 \mathrm{rpm}$ for 20 minutes at $4^{\circ} \mathrm{C}$. Washed twice with $70 \%$ ethanol, air-dried for 30 minutes and resuspended in $250 \mu 1 \mathrm{TE}$ buffer. (Williams 1990).

\section{Quantification of DNA and purity checking:-}

The yield of DNA per gram of leaf tissue were isolated and measured using a UV Spectrometer at $260 \mathrm{~nm}$. DNA concentration and purity was also determined by running the samples on $0.8 \%$ agarose gel depending on the intensities of band were compared with lambda DNA marker (Salmon 1996).

\section{RAPD Amplification:-}

The optimization of RAPD reaction using DNA extracted from Musa spp, oligonucleotide primers (Operon Technologies Inc., USA) were used for amplification to standardize the PCR reaction. The polymerase chain reactions was carried out in a Thermo cycler (Lark, India). Reactions without DNA were used as negative controls. Each $15 \mu \mathrm{L}$ reaction volume contained about $50 \mathrm{ng}$ of template DNA, 1X PCR Buffer (template DNA 3ul ,Dntps mix $3 u l$,forward primer, $1.5 \mu \mathrm{l}$ of revers primer, 2 ul of Taq DNA polymerase, $10 X$ assay buffer 1ul (Helini Biomolecules, India). The thermo cycler was programmed for an initial denaturation of 3 min at $94^{\circ} \mathrm{C}$, followed by 30 cycles at $94^{\circ} \mathrm{C}, 1 \mathrm{~min}$ at $37^{\circ} \mathrm{C}$, extension was carried out at $72^{\circ} \mathrm{C}$ for $1 \mathrm{~min}$ and final extension at $72^{\circ} \mathrm{C}$ for $5 \mathrm{~min}$ and a hold temperature of $4^{\circ} \mathrm{C}$ at the end (Penagos,2004).

\section{Visualization of DNA in Agarose gel:-}

Amplified DNA fragments were separated on 2\% agarose gel stained with ethidium bromide. Running buffer containing Tris-base, boric acid and EDTA ( $\mathrm{pH}$ 8.0) was used for electrophoresis and for preparing gels. Wells were loaded with $25 \mathrm{ul}$ of reaction volume and $5 \mathrm{ul}$ of loading buffer (sucrose and bromo-phenol blue dye) together. Electrophoresis was conducted at $50-60 \mathrm{~V}$ for $3 \mathrm{~h}$ and the gel were photographed under UV light using a gel dock system. (Saraswathi, 2011).

\section{Construction of dendrogram based on statistical analysis:-}

Size of amplified bands were estimated using gel pro analyzer software. The binary data set was used to calculate the pair wise Dice similarity index and to assemble the corresponding similarity matrix. The matrix obtained was used to generate a dendrogram using the UPGMA method (Unweighted Pair Group Method with Arithmetic Mean). The distances in the dendrogram were compared with the genetic distances between genotypes pairs to calculate the cophenetic correlation. All the analyses were performed with the aid of the 2010 version of the Lab Image Bio Imaging platform - Pc computer program (Soniya, 2001).

\section{Results and Discussion:- Sample Collection:-}

The different banana plants were collected from SPIC agriculture farm for isolation of genomic DNA shown in (figure 1). The collection of banana species was carried out by the methods as like (Lakshmanan. et al., 2007). Plant were cultured in MS media for 4 weeks period and studied for genetic variation.

\section{Quantification of DNA and Gel electrophoresis:-}

DNA was visualized and quantified under spectrophotometer by taking absorbance reading at $260 \mathrm{~nm}$ (Table 1). The highest amount of DNA was recovered from the Nendram $(0.017 \mu \mathrm{g} / \mathrm{l})$ and the lowest amount was obtained from Red banana $(0.01 \mu \mathrm{g} / \mathrm{l})$. The sizes of the amplified bands in the five banana varieties ranged from $250 \mathrm{bp}$ to 10,000 Obp (Table 2). The bands of primer OPA-03 ranged from 500 bp to 100,000bp; the bands of primer OPE-20 ranged from $300 \mathrm{bp}$ to $100,000 \mathrm{bp}$ Saraswathi (2011). All distinct bands or fragments (RAPD marker) were thereby given identification numbers according to their position on the gel and scored visually based on their presence (1) or 
absence (0), separately for each individual and each primer. Out of the amplification products recorded, $43.47 \%$ were monomorphic, common to all the genotypes. Whereas, $30.43 \%$ were unique, and only $26.08 \%$ revealed the relationship between these genotypes. Among the selected primers OPB-18 (Figure 2) produced maximum number of polymorphic 4 bands followed by OPA-19 and OPD-16. The pool of primers yielded reasonable number of polymorphic fragments for all the genotypes were examined. RAPD bands were manually scored from the gel profile, ' 1 ' for the presence and ' 0 ' for the absence of band and the binary data generated from all the profiles, were used for statistical analysis. The dissimilarity matrix was computed using Squard Euclidean Distance (SED) that estimated all pair wise difference in the amplification product. The dendrogram (Figure 3) was constructed by Ward's method 1973 of clustering using minimum variance algorithm. Cluster analysis revealed the 5 genotypes examined on the dendrogram with Grandnaine and Rasthali spanning the extreme. The genetic dissimilarity value ranges from 2.82 to $3.6 \%$ was observed. The highest dissimilarity $3.6 \%$ was detected between genotypes Red banana and Rasthali and the least $2.23 \%$ between genotypes Nendran and Rashali.

Table1:- Estimation of DNA

\begin{tabular}{|l|l|l|}
\hline S.No & Name of the Cultivars & Concentration of DNA \\
\hline 1 & Nendran & 0.017 \\
\hline 2 & Red banana & 0.001 \\
\hline 3 & Poovan & 0.002 \\
\hline 4 & Grand naine & 0.008 \\
\hline 5 & Rasthali & 0.005 \\
\hline
\end{tabular}

Table 2:- Molecular Weight Determination

\begin{tabular}{|l|l|l|l|l|l|l|}
\hline $\begin{array}{l}\text { Number Of } \\
\text { Bands }\end{array}$ & $\begin{array}{l}\text { Standerd } \\
\text { Molecular } \\
\text { Weight }\end{array}$ & $\begin{array}{l}\text { Sample 1 } \\
\text { (Nendran) }\end{array}$ & $\begin{array}{l}\text { Sample 2 } \\
\text { (Red banana) }\end{array}$ & $\begin{array}{l}\text { Sample 3 } \\
\text { (Poovan) }\end{array}$ & $\begin{array}{l}\text { Sample 4 } \\
\text { (Grand naine) }\end{array}$ & $\begin{array}{l}\text { Sample 5 } \\
\text { (Rasthali) }\end{array}$ \\
\hline 1 & 10000 & 10475 & 10316 & 10435 & 10475 & 10502 \\
\hline 2 & 9000 & 9614 & 9455 & 9574 & 9534 & 9137 \\
\hline 3 & 8000 & 6288 & 7110 & 6792 & 9018 & 6712 \\
\hline 4 & 7000 & 5228 & 5030 & 4924 & 6792 & 5427 \\
\hline 5 & 6000 & 4367 & 4327 & 4221 & 4844 & 4447 \\
\hline 6 & 5000 & & & & 4248 & \\
\hline 7 & 4000 & & & & & \\
\hline 8 & 3000 & & & & & \\
\hline 9 & 2000 & & & & & \\
\hline 10 & 1000 & & & & & \\
\hline
\end{tabular}


Figure 1:- Growth of Banana Variety

Fig a:- Grand Naine

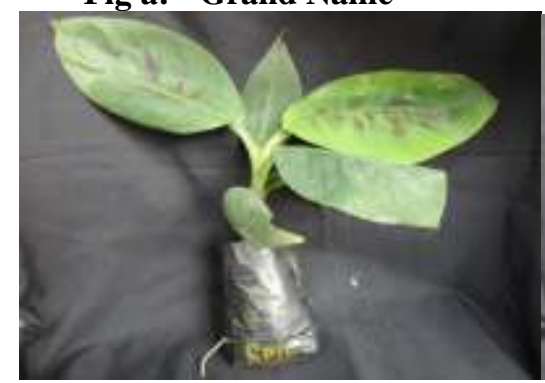

Fig c:- Nendran

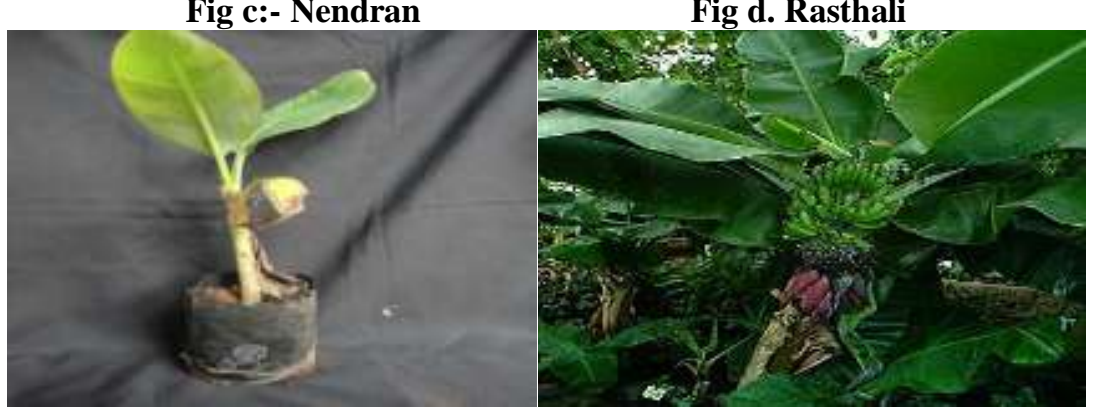

Fig b:- Red Banana

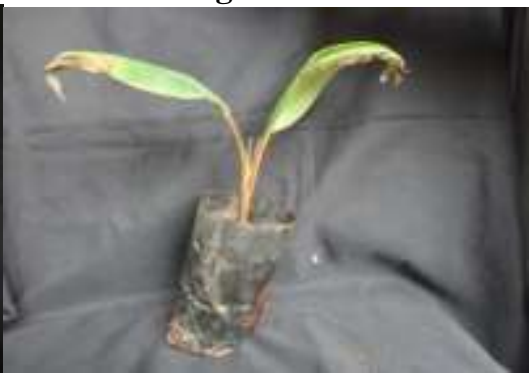

Fig d. Rasthali
Fig e:- Poovan

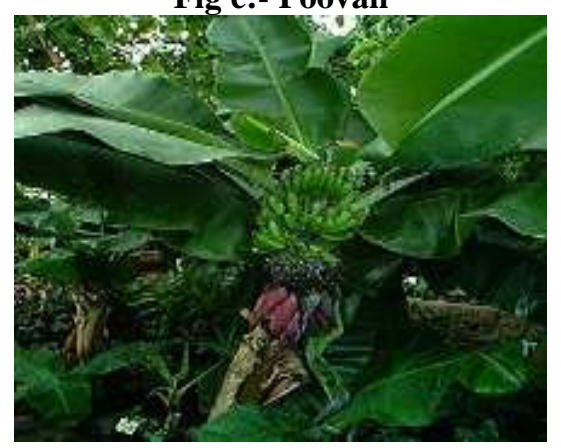

Fig 2:- Agarose gel electrophoresis of DNA

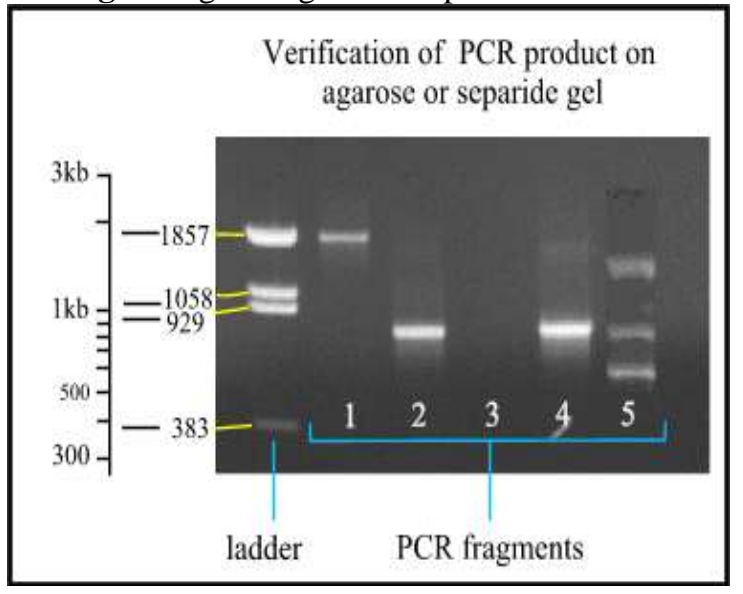

\begin{tabular}{|l|l|}
\hline 1 & Nendran \\
\hline 2 & Red banana \\
\hline 3 & Poovan \\
\hline 4 & Grand naine \\
\hline 5 & Rasthali \\
\hline
\end{tabular}


Fig 3:- Amplified fragments of RAPD Analysis
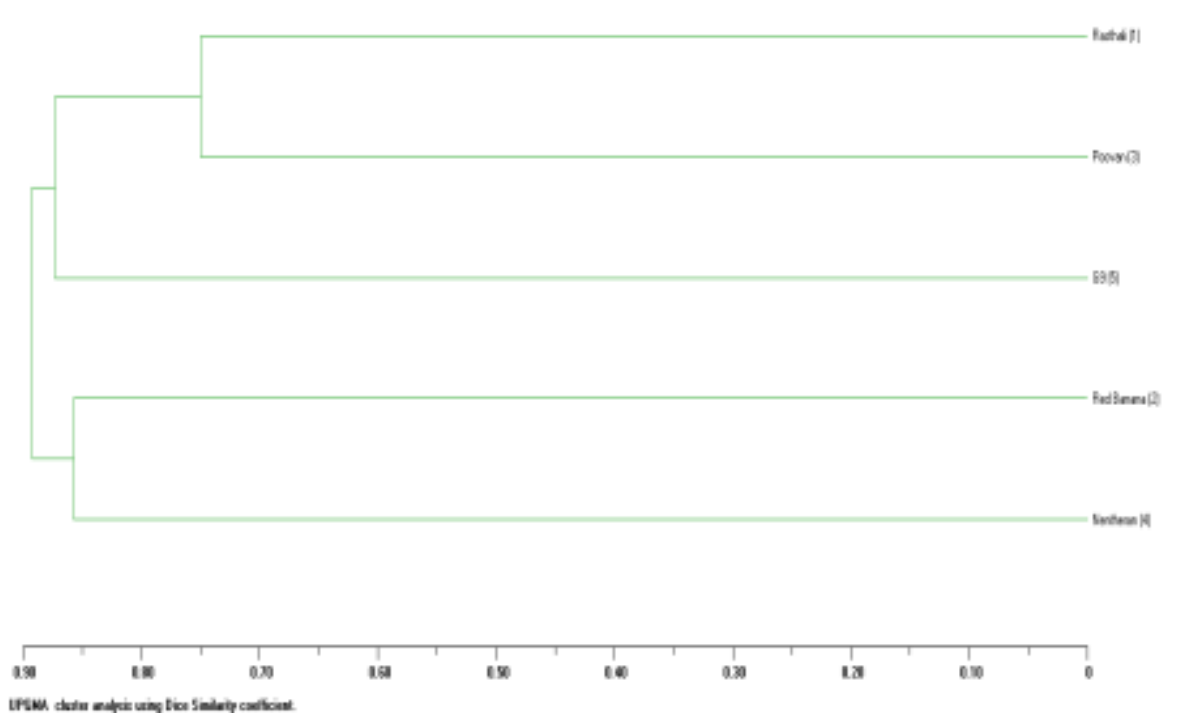

\section{Conclusion:-}

India has immense wealth of banana germplasm that ranks as second most important fruit crop of the country both in area and production. The focus of this study was to examine musa acuminatae (Banana) DNA. In this study the DNA of the banana were extracted and homogenized with Lysis buffer. Genetic diversity of DNA was identified. The gel electrophoresis study confirmed the presence of DNA in the sample. Thus the DNA of the leaves could be able to identify and distinguished from other organisms DNA.

\section{Bibliography:-}

1. Brarl D.S.,Jain, S.M. (2009). Somaclonal Variation: Mechanisms and Applications in Crop Improvement. USA: Kluwer Academic Publishers. 17-37.

2. Padam, B.S., Tin, H.S., Chey, F.Y., Abdullah, M.I. (2012). Antibacterial and Antioxidative Activities of the Various Solvent Extract of Banana (Musa paradisiacal cv. Mysore) Influrescences. Journal of biological science, 12(2): 62

3. Saraswathi M.S, Uma S, Selvam KP, Ramaraj S, Durai P, Mustaffa MM (2011). Assessing the robustness of IRAP and RAPD marker systems to study intra-group diversity among Cavendish (AAA) clones of banana. J Hortic Sci Biotech 86:7-12.

4. Salmon, B.; Martin, G. J.; Remaud, G. \& Fourel, F. (1996). "Compositional and Isotopic Studies of Fruit Flavours. Part I. The Banana Aroma". Flavour and Fragrance Journal. 11 (6): 353-359.

5. Penagos H. (2004). Pesticide patch test series for assessment of allergic contact dermatitis among banana plantation workers in panama Dermatitis. 15(3):137-45.

6. Soniya E.V, Banerjee N.S, Das M.R (2001). Genetic analysis of somaclonal variation among

7. storage under minimal growth conditions of Musa (banana and plantain). Plant Cell Report. 4: 351-354.

8. Lakshmanan.V, Sreedhar .R Venkataramareddy. B Neelwarne (2007). "Molecular analysis of genetic stability in long-term micro propagated shoots of banana using RAPD and ISSR markers", Electronic Journal of Biotechnology, 1(10).

9. Wards, (1973) Analysis of gene diversity in sub dived populations proc.nalt.acad.sci. Risesberg. USA 70. 3321.3323.

10. Williams, J. G K., A. R. Kubelik, K. J. Livak, J. A. Rafalski, and S. V. Tingey. (1990). DNA polymorphism amplified by arbitrary primers is useful as genetic marker. Nucleic Acids Res 18:6531-6535. 